\title{
Ford Madox Brown, Work
}

\section{Tim Barringer}

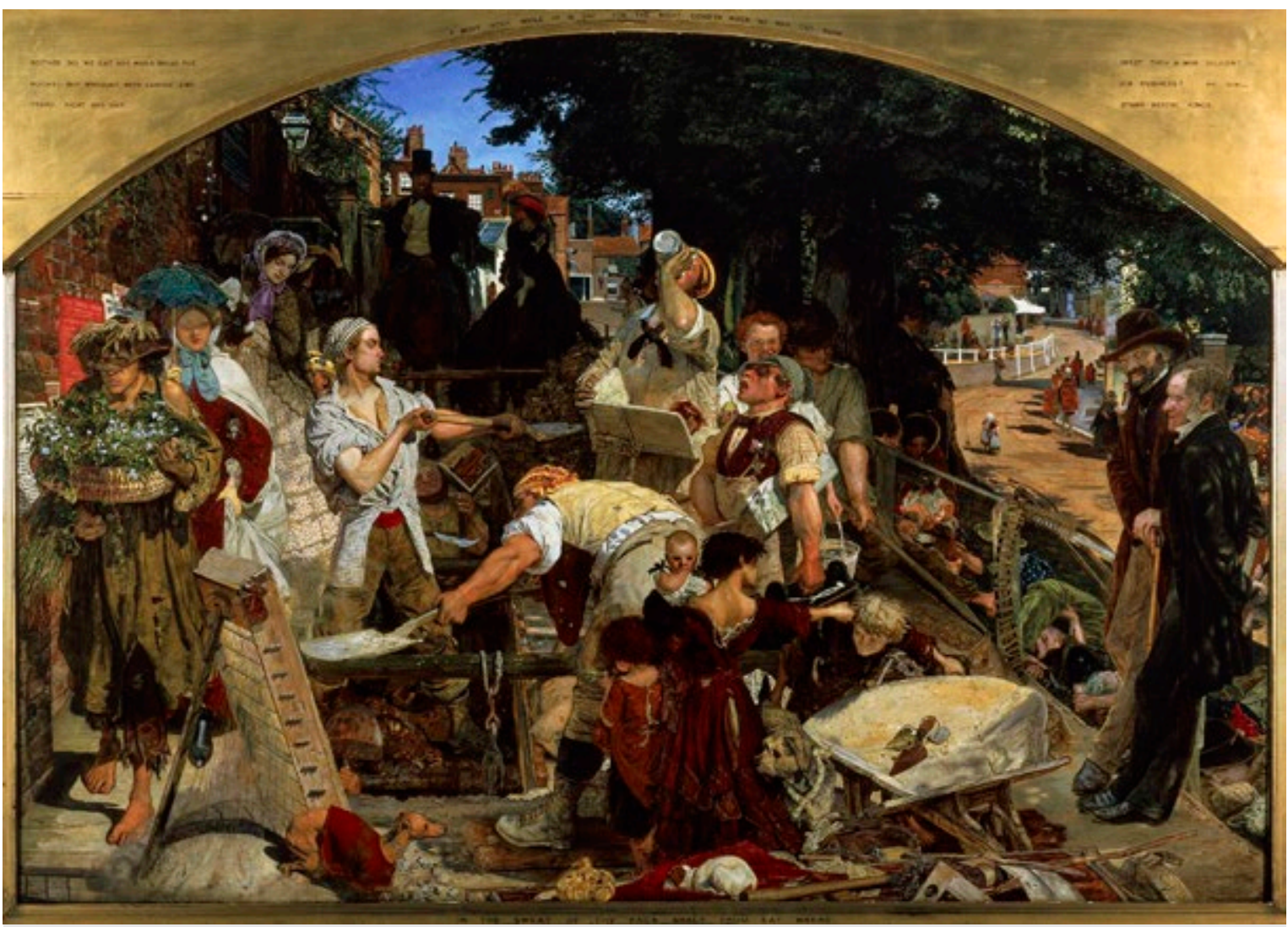

Ford Madox Brown, Work, 1852-1863

Ford Madox Brown's allegory of labor in all its forms is the most ambitious PreRaphaelite painting of modern life and a profound meditation on the relationship between art, religion, and labor in Victorian society. Brown began the composition in Hampstead in 1852, but continued to elaborate it for another eleven years, finishing it after a vast expenditure of labor in 1863 . He exhibited it in a pioneering one-man show in 1865 .

In this visual treatise on labor and salvation, Brown included portraits of two significant contemporary thinkers on the same theme: the philosopher Thomas Carlyle, depicted with a strange, satirical leer, and the beatific churchman Frederic Denison Maurice, next to Carlyle in the right foreground. They shared with Brown the notion that work tests, and displays, the moral fiber of the individual. Brown inscribed the frame with biblical quotations pointing to this theme:

In the sweat of thy face shalt thou eat bread (Genesis 3:19)

Neither did we eat any man's bread for naught but wrought with labour and travail night and day (2 Thess 3.8) 
I must work while it is day for night cometh, when no man can work (John 9:4) Seest thou a man diligent in his business? He shall stand before Kings (Proverbs 22: 29)

Work, then, is a religious history painting for a secular age, reflecting Carlyle's belief that "there is a perennial nobleness, and even sacredness, in work."

The heroes of this painting are the manual laborers whose bodies form a massive pentagonal mass in the center, brilliantly lit by the hot summer sun. They are navvies, men of formidable strength whose job was to dig trenches, in this case for the installation of new fresh-water pipes. Normally such laborers would have been considered too vulgar to appear in a work of high art, but Brown took the opposite view. The pose of the central navvy who, Brown wrote, "occupies the place of hero," alludes to the Apollo Belvedere, the classical statue in the Vatican collection much reproduced as a plaster cast and long considered the epitome of male beauty. ${ }^{2}$ Yet more striking is the similarity of these figures to the manly image of Christ seen in Brown's Jesus Washing Peter's Feet (London, Tate) begun the same year, 1852, and purchased, like Work, by the Leeds Evangelical preacher, cobbler, and art collector Thomas Plint. The navvies, caught in the blazing sunlight of revelation, embody the Victorian Broad Church creed of salvation through labor. To link the proletarian navvies with ideas of nobleness and moral value-and ultimately with Christ himself-as well as with beauty, was a remarkable, radical statement.

The painting offers a range of figures for comparison with the navvies and philosophers. Each character demands slow and careful interpretation, as in a Victorian novelmaking the viewer work just as the artist had done. Behind them is an aristocrat mounted on horseback, chatting with his daughter. They are thrown into the shadows, irrelevant. The man's expression suggests sympathetic interest in the social problems of the day, but he is too far from the action to make a difference.

A pious middle class lady distributing temperance tracts, to the left in a purple bonnet, is also subjected to satire. The navvies drain their pints of beer and have screwed up one of her leaflets and tossed it into the wheelbarrow at front right.

By contrast, to the right, shaded on the bank, is a group of unemployed haymakers. We can sympathize with their plight. Brown applauds the efforts of a young couple to feed their small child: a young mother's yellow bonnet suggests a halo, linking this poorest of women with the Virgin Mary. Among the many other characters who deserve our sympathy are the poor orange seller, ejected by a policeman at the right, and the "ragged wretch who has never been taught to work" to the left margin. ${ }^{3}$

Critical response was favorable, with one critic noting that, given the visibility of the artist's own labor, Brown "is well entitled to give his opinion of what constitutes hard work." 4 For the Athenaeum, the painting was "Brilliant, solid, sound, studied with extraordinary earnestness, elaborate and masterly." 5 After more than a decade of struggle, Brown declared in 1864 that the finished canvas embodied no less than "the work of my life."6 It constituted the profession of an idiosyncratic religious faith as well 
as the elaboration of an artistic and political manifesto.

(C) Tim Barringer

\section{Citation Guide}

1. Tim Barringer, "Ford Madox Brown, Work," Object Narrative, in Conversations: An Online Journal of the Center for the Study of Material and Visual Cultures of Religion (2014), doi:10.22332/con.obj.2014.42

Barringer, Tim. "Ford Madox Brown, Work." Object Narrative. In Conversations: An Online Journal of the Center for the Study of Material and Visual Cultures of Religion (2014). doi:10.22332/con.obj.2014.42

\section{Notes}

1. Thomas Carlyle, Past and Present (1843; reprint, London: Everyman, 1912), 189.

2. Ford Madox Brown, The Exhibition of WORK, and other Paintings, by Ford Madox Brown, at the Gallery (Piccadilly, London: M'Corquodale, 1865), 191, quoted in Kenneth Bendiner, The Art of Ford Madox Brown (University Park: Pennsylvania State University Press, 1998), 156.

3. Ibid.

4. The Builder, 18 March 1865, 186.

5. Athenaeum, 11 March 1865, 353.

6. Ford Madox Brown to George Rae, 1864, quoted in Mary Bennett, "The Price of Work," in Pre-Raphaelite Papers, ed. Leslie Parris (London: Tate Gallery, 1984), 151.

\section{Yale}

Copyright 2016 Yale University All rights reserved. 